\title{
A Study on Chinese-English Translation of Company Profile From the Perspective of Skopos Theory-A Case Study of Ningbo Textile Companies
}

\author{
WANG Yin \\ Ningbo Dahongying University, Ningbo, China
}

\begin{abstract}
A high-quality English version of the company profile is not only an important tool for enterprises to promote their culture, but also like a business card provides target customers with a quick access to the general understanding of the company. With the impact of economic globalization, more and more companies have entered the international market with a bilingual company profile. However, the quality of the English version is dubious and unacceptable, which seriously hinders the effective communication between the company and target customers. Under the guidance of Skopos Theory, taking Ningbo textile company profiles as examples, the paper analyzes the translation problems from the two parts of linguistic expressions and culture and puts forward some translation strategies so as to provide a reliable theoretical basis for the English translation of textile company profiles.
\end{abstract}

Keywords: Skopos Theory, company profiles, Ningbo textile companies, translation strategies

\section{Introduction}

Corporate profile is a special form of "soft article marketing". Compared with the advertising campaign, it has a marketing advantage of spending less money but attracting more customers. From a company profile, customers can know the size and development of a company. With the successful hosting of G20 in Hangzhou, it not only enhances the image of China, but also raises the benefits and level of opening-up. Closer international trade will become a major trend in the future of the global economy. As an important part of the enterprise's external publicity, the translation of corporate profiles is the inevitable product of the development of enterprises. Through the collection and analysis of literature, the author finds that corporate profile translation has been studied by some scholars. Based on the Adaptation Theory, JIN Mei-yu (2011) points out that translators should adopt the translation strategies of "highlight key information" and "concise structure" to modify the original text with "addition" and "deletion" so as to conform to the information structure of the western text. YAN Jia-xin (2014) analyzes three problems of enterprise content, language, and structure from the perspective of Skopos Theory, and the corresponding translation strategies have been proposed; meanwhile, she also demonstrates that it is important for translators to have a sense of purpose.

Ningbo is the birthplace of Hong Band Tailors, which has a profound cultural heritage of textile. Since the reform and opening-up, Ningbo textile industry has formed a relatively complete production chain from the raw materials, weaving, printing, and dyeing to others. Although many textile companies in Ningbo are equipped

WANG Yin, senior student, English Department, Ningbo Dahongying University. 
with Chinese and English profiles on the company website or promotional materials in order to expand the foreign market, most of them are unaware that there are some translation problems in their English version. In this paper, based on the summary of the study of foreign textile companies, author considers Skopos Theory can provide a fresh perspective, which helps to find translation problems and provides effective translation strategies to the C-E translation of Ningbo textile company profiles.

\section{General Introduction of Skopos Theory}

\section{Skopos Theory and Its Three Principles}

'Skopos is the Greek word for 'aim' or 'purpose' and was introduced into translation theory by Hans J. Vermeer as a technical term for the purpose of a translation and of the action of translating" (Munday, 2001, p. 78). The establishment of the theory can be traced back to the sixties of the 20th century. Its main idea is that translators should hold the thought from the perspective of target readers during the process of translation. Translators should consider now and then about what the function of translation text is, what the target reader' demand is and even what communicative situation is. Thus, the choice of translation strategies is determined by the purpose of the translation text.

Skopos Theory has three principles. The first is skopos principle. It points out that a translation action is determined by its skopos. Thus, the translation strategies are determined by the purpose needed by the translation, which means that the translation should adapt to the target language behavior (ZHANG, 2015). The second is coherence principle. It states that the target text must be interpretable as coherent with the target text receiver's situation. Besides, the translation is no longer part based on the source text, but only part of the translation belief. It is just an offer of information for the translator, who in turn picks out what he considers to be meaningful in the receiver's situation. The third is fidelity principle. It concerns inter-textual coherence between translated and source text, and stipulates merely that some relationship must remain between the two once the overriding principle of skopos and the principle of coherence have been satisfied.

\section{The Guiding Significance of Skopos Theory to Ningbo Textile Company Profiles}

In translating the company profiles, it includes far more than replacement of lexical and grammatical items between languages. The process may involve discarding some linguistic elements of source text and producing an ideal target text to fulfill the intended functions. Therefore, the company profile translation needs special treatment, calling for an effective theory to guide its practice (HE, 2012). The author believes that Skopos Theory is rather conductive to the identifying of the specific purpose of translation and gives a new perspective to study. Firstly, translators should know the text type and make sure the purpose of company profiles. The purpose of company profiles is to attract foreign customers and promote sales. It requires the original text must be translated into the target text which can be accepted by target customers. Secondly, according to Skopos Theory to find the translation errors which may exist in linguistic level and culture level because any translations cannot be avoided by the expression of language and culture. Thirdly, based on Skopos Theory, there are some flexible and effective translation strategies to optimize the translation. In a word, Skopos Theory has a guiding significance of the company profile translation.

\section{Overview of Textile Company Profiles}

Company profile is an indispensable material for external publicity, which provides information about the company and convinces consumers to purchase its products. Before translating the textile company profile, the 
translator should have a good understanding of what features and functions it is so as to achieve the ultimate goal of translation (LING, 2015).

There are two main features of Ningbo textile company profiles summarized by the author. The first is stylistic features. Company profile is a practical text. Through the analysis of Ningbo textile company profiles, the author finds that the structure of Chinese textile company profiles can be summarized as follows: (1) company basic information (company type + specific address description); (2) company size (staff + area + equipment ) + monthly output; and (3) willingness, slogan, and future prospects. Due to the characteristics of textile industry, target customers pay more attention to the quality, comfort, practicality, and design innovation of a company. In addition, an enterprise's production chain and equipment advantage will also become the measured factors to evaluate the quality of a company. Therefore, translators should pay more attention to the textual characteristics of the textile industry and the expression of related technical terms. The second is specialization. Each industry has its own unique industry terminology and product terminology, so does the textile industry. It requires translators to consciously accumulate some relevant terms, such as: 锦纶丝 Polyamide Yarns; 尼丝纺 nylon taffeta (nylon shioze); 羊毛双面呢 double-faced woolen goods; 耐磨 abrasion resistance; 抗起球 anti-pilling.

In a word, a clear understanding of the features of textile companies is the premise of the better translation of textile company profiles. According to the features, the translator can translate a convincing English version of the textile company. It not only contains enough persuasive messages which can stimulate the purchase desire of customers, but also greatly enhances the competitiveness of textile companies in the international market.

\section{Translation Problems in C-E Translation of Textile Company Profiles}

\section{Translation Problems in Linguistic Expressions}

In the C-E translation of Ningbo textile company profiles, the most basic problems and errors are often derived from the ignorance of language expressions, which can be analyzed from three aspects: lexical, syntactical, and discourse level.

At lexical level. The translation problems at the lexical level in Ningbo textile company profiles mainly include the two types, namely the inaccurate translations and redundant words.

Table 1

Inaccurate Translations

\begin{tabular}{llll}
\hline Items & Chinese & English translation & Revision \\
\hline \multirow{2}{*}{$\begin{array}{l}\text { Conventional } \\
\text { vocabularies }\end{array}$} & 各种各样的 & Verious & Various \\
& 产品 & Priducts & Products \\
& 设备 & Equipments & Equipment \\
\hline \multirow{2}{*}{ Conventional terms } & 拥有自营进出口权 & With self-managed import \& export right & Own rights of import-export operations \\
& 核心竞争力 & Core competition & Core competitiveness \\
& 通过了XX认证 & Passed XX & Be certified by XX \\
& 以顾客为导向 & Customer first & With orientation for clients \\
\hline \multirow{2}{*}{ Industry terminologies } & 全羊毛纱 & All wool yarn & Wool (100\%) Yarns \\
& 雪花天我线 & Snow velvet & Melange velvet \\
\hline
\end{tabular}

Example A1: 主要产品以出口为主, 销往美国、欧洲、澳大利亚、日本、韩国、香港及台湾等国家 和地区。(宁波罗圣纺织品有限公司) 
English version: Most of our products are for exports, they are well sold in USA, Europe, Australia, Japan, Korea, Hong Kong and Taiwan, etc. (Ningbo Luosheng Textile Co,. Ltd)

As for the problem of the lexical level, some typical errors in textile company profiles have been demonstrated in Table 1. The first is that there are some low-level spelling errors, which are caused by the translator's irresponsible attitude. The second is the inaccurate translation of conventional terms and industry terminologies, which reveals that the translator is not professional and has little accumulation of terminology translation. In addition, the Example A1 reflects a phenomenon of redundant words. "the United States, Europe, Australia, Japan, Korea, Hong Kong and Taiwan" can be simply replaced by "market in China and across the world", which is easier for customers to understand and it is also consistent with the coherence principle of Skopos Theory.

At syntactical level. During the translation of company profiles, the translator should take the sentence order into account. Because of the different expressions of Chinese and Western, the translator should adjust the syntactical structure to be in line with the target language.

Example A2: 宁波海洋纺织品有限公司是一家专业从事家用纺织品生产商, 位于宁波市, 距离上海 有 2.5 小时的车程。我们在产品的设计, 开发, 制造和销售上有 15 年的经验。(宁波海洋纺织品有限公司)

English version: Ningbo Ocean Textiles Co., Ltd. is a professional home-textile manufacturer, located in Ningbo City, which is 2.5 hours drive from Shanghai. We have 15 years of experience in, developing, manufacturing and selling a wide range of home-textile products. (Ningbo Ocean Textiles Co., Ltd.)

It is improper for translators to use the word for word translation instead of analyzing and adjusting the sentence structure first. Although the English version seems to be faithful to the original text, the expression is not clear, which is contrary to the coherence principle. Therefore, the translator should grasp the main idea of a sentence first, then use word segmentation or preposition structure to express the other parts. Thus, the English version of Example A2 could be translated into "Ningbo Ocean Textiles Co., Ltd. is a professional home-textile manufacturer. We have 15 years of experience in providing a coordinated service of product designing, developing, manufacturing and marketing".

At discourse level. Different countries have different ways of thinking, writing habits, and culture, which determines the text under different cultures have different discourse structures. Meanwhile, it also demonstrates that translation is not only a symbolic conversion, but also the process of restructuring of the original text. However, some translators ignore the importance of text reconstruction, which makes the English version cannot be accepted well by target customers, thus violating the purpose of its translation.

Example A3：宁波锦集纺织有限公司是一家专业生产全棉平线（天鹅线）、粗纺呢线和窗帘、被套 等家纺产品的厂家。……座落于浙江省余姚市黄家埠镇回龙工业区，地处杭州、宁波两市中间 (各约60 公里), 近临329国道, 地理优越, 交通便利。公司现有员工 800 余人，各专业技术人员 60 余人，厂区面 积 $38000 \mathrm{~m}^{2}$ 。本公司拥有平线织机 260 台, 毛呢织机剑杆45台及多台染色整理生产设备。月可生产平线(天 我线) 产品 100 万米, 毛呢类产品 20 万米及各种窗帘、床上用品等家纺产品。公司多年连续被评为AAA级 守信用企业……公司于2003年先后通过了IS090014001环境管理体系和IS09001：2000质量管理体系认 证……集团公司本着保优创新、高效运行, 形成“高档产品技术领先, 常规产品花色齐全”的经营特色, 随时满足客户需求, 以吸引众多国内外客户。（宁波锦集纺织有限公司）

English version: Ningbo J-Group Textile Co., Ltd. located in Huilong Industrial Zone, Huangjiabu Town, Yuyao, which is between Hangzhou and Ningbo (about $60 \mathrm{~km}$ both) and is near 329 National Highway, with excellent position and convenient traffic. Covering an area of $38,000 \mathrm{~m}^{2}$, the company has a staff of..., and form 
characterized management of "advanced technique of high-grade products and diversified types of common products" to cater for more and more customers (Ningbo J-Group Textile Co., Ltd.)

The Example A3 is one of textile company profiles analyzed by the author. Like other textile company profiles, the English version uses the word for word translation and this makes the content of the English version unfocused, causing customers to lose interest directly, so the structure of the English version should be restructured to comply with the coherence principle.

\section{Translation Problems in Culture}

Translation is a kind of process not only in language transformation but also in cross-cultural contact. In enterprise publicity materials, the adaptation principle has been mentioned, namely cultural difference, which mainly reflects in values, aesthetic interest, thinking mode, and expression. Because of translator's ignoring the differences between different cultures, the translation's violation of the target language culture is commonly seen. Therefore, if translators do not get enough acquaintance about different cultures, their translation will be counterproductive, affecting the communicative purpose of translation and making cultural translation errors (ZHANG, 2015). Here are some examples of the translation problems of culture.

Chinese cliché. In order to firmly express the company's business philosophy and values, some Chinese clichés have been used in their company profiles. Although Chinese customers are accustomed to these expressions, the translation of Chinese cliché is extremely difficult for foreign readers to understand, who choose to be an instant turnoff because these phrases are just unnecessary.

Example A4: 公司坚持不断创新, 致力追求高、精、美、实的产品质量, 严格奉行信誉第一、顾客 至上的服务宗旨, 创造高雅整洁的办公环境, 良好独特的人文氛围, 让客户满意、让员工满意是我们的 厚望。(宁波高广纺织品有限公司)

English version: Companies adhere to constant innovation, committed to the pursuit of high-grade, the United States, indeed the product quality, strictly adhered to the credibility first, customer supreme principle of service, and create an elegant and clean office environment, good atmosphere of the unique culture, so that customer satisfaction, employee satisfaction so that it is our expectations. (Ningbo Gaoguang Textiles Co., Ltd.)

In Chinese corporate profiles, the official jargons are widely adopted such as “致力追求”, “严格奉行...... 服务宗旨”, “信誉第一”, and so on. From the Example A4, the translation seems to follow fidelity principle, but the fact is not. Through the learning of Skopos Theory, the author knows clearly that skopos principle is the key principle of Skopos Theory and the translation should be carried out on the basis of its purpose. The translation of Example A4 is inadequate, which is against the skopos of translation. For target customers, these are useless information. So translators just catch the main information deeply and translate them into the target text instead of translating them with word for word method.

Invalid information. In Chinese textile corporate profiles, the issued honors and certificates have always been introduced in order to attract customers and gain their trust. For Chinese people, the more awards the company has won, the better the company is. But as for foreign customers, they are hard to understand the translation because some certificates are peculiar to the Chinese people, so there is still a problem of the honorary translation caused by ignoring the cultural factors.

Example A5: 公司已通过宁波市绿色企业审核、宁波市清洁生产审核、国家IS09001: 2008质量管理 体系认证、IS014001：2004环境管理体系认证。在国家工商局注册登记了“旭丰”牌商标，多次评为县、 
市文明单位，宁波市和谐企业称号，多次荣获县纳税大户称号，并荣获在2012年中国棉纺织一色纺纱 行业经济效益指标排序中出口交货值、人均利税、劳动生产率前十名证书、在 2012 年中国棉纺织行业经 济效益指标排序中出口交货值、人均利税、劳动生产率为前 100 名证书。2014年，公司通过了浙江省绿 色企业审核。(宁波华东旭丰纺织品有限公司)

English version: Upholding the management tenet of "very strict control over management, product quality and safety", our company has built well-formed and complete regulations and has attained the Check certificate of Green Enterprise of Ningbo city, Check certificate of Clean Production of Ningbo city, the certificates of ISO9001: 2008 Q.C. system and ISO14001: 2004 EMS. We are also honored as the Good Unit of Province, .... and the TOP-100 Enterprise of Cotton Textile Industry of China in terms of the indexes of economic effectiveness (Export delivery value, profit \& tax per person and labor productivity, etc.). (Ningbo Huadong Xufeng Textiles Co., Ltd.)

The whole text is the description of the company’s honors and certificates, such as “宁波市和谐企业”, “国家ISO9001: 2008质量管理体系认证” and “县、市文明单位”, and so on. For Chinese customers, it is a good measure to evaluate whether a business is good or bad. So the translator uses the word for word translation to show the advantages of enterprises with 162 translated words. But for target customers, the description of honors and certificates is useless information, which is difficult to understand and even reduces business value. Thus, the translated text fails to realize its direct purpose. In order to give target customers a better impression and show their values clearly, the author suggests that the translator should translate internationally recognized certificates or choose inductive methods to summarize their honors like "We have been certified by ISO9001: 2008 and ISO14001: 2004, and also have been granted many honorable titles".

\section{Translation Strategies in Light of Skopos Theory}

Through the analysis of the problems and errors in the C-E translation of Ningbo textile company profiles, the author puts forward two effective strategies based on Skopos Theory, namely abridgement or omission and restructuring, which can make textile company profiles to be more standardized and attractive.

\section{Abridgement or Omission}

Although abridgement and omission are commonly used translation strategies, the role of them cannot be ignored in the translation of textile company profiles. Abridgement means that the translator should understand the meaning of the original text first, then catch the main idea and delete the unimportant or irrelevant information, such as flowery expressions and sentences, which often appear in the value expression and the slogan of corporate profiles. It only adds to the trouble of reading. Thus, the role of abridgement is to achieve the goal of conciseness and brevity and accepted by target customers. Omission refers to the deletion of useless words or passages based on the understanding of the cultural difference, such as prizes or awards, Chinese poems or idioms, and so on. Whether it is abridgement or omission, the purpose of both is to achieve economy and bring the useful information into full play.

The above Example A4 is an example of the expression of values and there are some sentences, which need translators to delete some useless information and then make some abstract information specific. For example, “严格奉行信誉第一、顾客至上的服务宗旨” is a slogan expression, which is translated into “strictly adhered to the credibility first, customer supreme principle of service" in the English version of Example A4. It is obvious that the English version is the word for word translation and the words “严格奉行” and “服务宗旨” 
are official jargons with making no sense since target customers are entirely unconcerned with Chinese government policies, so translators should use abridgement or omission to reproduce these jargons in a natural and concise way. Based on the learning of foreign textile company profiles, the author finds that Boston textile company has a good expression of value, which is worth learning. For example, "We know you are concerned about value, about getting the best products for reasonable prices", namely the company knows that customers are concerned about the value of affordable prices to buy the best products. This content of the sentence is sincere and not meaningless information; meanwhile, it also definitely expresses their customer-oriented values. As for the expression of products, “致力追求高、精、美、实的产品质量” basically expresses the same meaning, that is, the high-quality of products. So the translator should use abridgement to delete the superfluous expressive information. In the English version, it is translated by "committed to the pursuit of high-grade, the United States, indeed the product quality". This expression is inappropriate and makes target customers feel confused. However, the expression of Boston textile company is also worthy of our study. "the most durable, proven, cost-effective products to meet your needs" this expression eliminates the useless words in the original text and makes the high-quality products specific, which makes target customers better understand. Thus, the author believes that the translation should focus on the needs and desires of target customers, and then use abridgement or omission to make the English version closer to the reader's reading habits. Those translation strategies are consistent with the skopos principle and the coherence principle.

\section{Restructuring}

A good text reconstruction, like a gorgeous appearance of a palace, can attract target customers and leave a positive attitude. Nowadays, textile company profiles exist in the phenomenon of homogeneity and most of them are a lot of seemingly unnecessary wanderings about the topic. However, based on the research of foreign textile company profiles, the author finds that the core information in their text is made clear first, and then give some examples and reasons to support or expound the main idea. That is to say, logical distinctions among different languages affect can influence the way of organizing a text. Thus, the difference requires the translator to restructure the structure and content of the original text by deleting, adding, or reorganizing with the essence of the original text intact, thereby improving the readability of the target text.

The above Example A3 is a typical case of structural chaos. From it, the author finds that the original text is above 350, and the English version is about 200 (the example is simplified with “...”). The main content includes: (1) company basic information (company type + specific address description); (2) company size (staff + area + equipment $)+$ monthly output; and (3) willingness, slogan, and future prospects. While through the analysis of references like Zara, Boston Textile, Özak Textile, the author summarizes the content as follows: (1) company basic information (established time + type + brief location); (2) main products + its advantages + company achievements; and (3) future development and vision. Obviously, foreign textile companies pay more attention to the usefulness and conciseness of content. Among them, the author finds that a number of textile company profiles focus on highlighting the geographical advantage of Ningbo, and even have a detailed description of the distance between Ningbo and Shanghai. In addition, the detailed description of equipment like “本公司拥有平线织机260台, 毛呢织机剑杆45台及多台染色整理生产设备”, which expresses the advantage of equipment, can be translated into " have well-equipped facilities". Besides, the author suggests that the issued awards or certificates should be placed under the title of the company name in order to attract target customers. By summarizing the content and structure of Example A3, the author translates it as follows: 
Ningbo J-Group textile Co., Ltd.

(ISO90014001; ISO9001: 2000; AAA grade Credit Enterprise)

Ningbo J-Group textile Co., Ltd., located in Yuyao, is a professional manufacturer of cotton velveteen (velvet), woolen cloth and curtains, quilt and other textile products. We have built a competitive market in China and across the world for the most durable, proven, cost-effective products. Covering an area of 38,000 square meters, we employ more than 800 employees and have well-equipped facilities. We aim to meet customer demand and take "Innovation, high-quality and high-efficiency operation" as its business philosophy.

\section{Conclusion}

Through the above analysis, it can be found that there are still some translation problems, which are against Skopos Theory in the English version of Ningbo textile company profiles. Among them, linguistic expressions and culture are the main reasons which lead to the low-quality of English versions. The author believes that it is important for translators to know the needs and desires of target customers before they translate, and then employ the above-mentioned strategies to translate a high-quality English version of company profile, thereby enhancing the corporate image and international competitiveness.

\section{References}

HE, H. (2012). 从功能翻译理论看企业简介英译一以广西企业简介为例 (Functionalist approaches to C-E company profile translation: With company profiles in Guangxi as case of study). 南宁: 广西大学.

JIN, M. Y. (2011). 从顺应论看公司简介英译中的“取”与“舍” (Study on “taking” and “giving up” in the English translation of company profiles from the perspective of adaptation theory). 长春理工大学学报, 10.

LI, D. (2012). 从功能翻译理论看企业简介的英译 (Analysis of Chinese profile translation-From the Perspective of functionalist approaches ). 荆州: 长江大学.

LING, Y. N. (2015). 目的论观照下的企业简介汉英翻译研究一以广西企业为例 (A study of profile C-E translation of Guangxi companies: A skopo approach ). 南宁: 广西大学.

Munday, J. (2001). Introducing translation studies: Theories and application. London: Routledge.

Nord, C. (2001). Translating as a purposeful activity: Functionalist approaches explained. Shanghai: Shanghai Foreign Language Education Press.

Reiss, K. (2004). Translation criticism: Potentials and limitations. Shanghai: Shanghai Foreign Language Education Press.

TAN, H. (2014). 文本类型理论下的企业简介翻译研究一以中国东盟博览会参展广西企业为例 (A study on the translation of company profile from the perspective of text typology theory-A case study of Guangxi companies participated in CHINA-ASEAN exposition). 海外英语, 7 .

YAN, J. X. (2014). 从目的论视角探讨企业简介的英译策略 (A study on the translation strategies of company profiles from the perspective of Skopos Theory). 海外英语, 5 .

ZHANG, L. L. (2015). 目的论视角下的企业简介英译 (Study on the translation of company profiles under Skopos Theory). 宁 波: 宁波大学. 